\title{
Effectiveness of the bone ring technique and simultaneous implant placement for vertical ridge augmentation: a systematic review
}

Luis Miguel Sáez-Alcaide ${ }^{1 *}$, Jorge Cortés-Bretón Brinkmann, Luis Sánchez-Labrador ${ }^{1}$, Fabián Pérez-González , Pedro Molinero-Mourelle ${ }^{2,3}$ and Juan López-Quiles ${ }^{1}$

\begin{abstract}
Background: Dimensional changes after dental extraction frequently lead to situations in which bone augmentation procedures are required prior to dental implant placement. Bone ring technique (BRT) has been described as a onestage approach to restore vertical alveolar ridge defects, in which an autogenous or allogeneic cortico-cancellous bone block graft is stabilized with a dental implant inserted simultaneously. The objective of this systematic review was to evaluate the clinical performance of BRT.

Materials and methods: This review was conducted according to PRISMA guidelines. An electronic search was conducted in four databases: (1) The National Library of Medicine (MEDLINE/PubMed) via Ovid; (2) Web of Science (WOS); (3) SCOPUS; and (4) Cochrane Central Register of Controlled Trials (CENTRAL). The Newcastle-Ottawa Quality Assessment Scale and The Joanna Briggs Institute Critical Appraisal tool were used to assess the quality of evidence in the studies reviewed.

Results: Sixteen studies with a total of 186 patients treated with 219 bone rings bocks were included in the review. The studies showed a mean bone gain of $4.94 \mathrm{~mm}$, mean bone resorption of $0.83 \mathrm{~mm}$, and mean marginal bone loss of $0.57 \mathrm{~mm}$ after a mean follow-up period of 13.35 months. A mean bone ring survival rate of $97.26 \%$ and implant survival rate of $94.97 \%$ were recorded.

Conclusions: BRT would appear to be an adequate alternative technique for restoring single vertical alveolar ridge defects with simultaneous dental implant placement. However, further studies comparing this technique with other vertical ridge augmentation procedures in different clinical scenarios are needed to confirm the present results.
\end{abstract}

Keywords: Vertical ridge augmentation, Alveolar ridge defects, Bone ring technique, Simultaneous implant placement

\section{Introduction}

Numerous studies have reported dimensional changes in the alveolar bone after dental extraction $[1,2]$. It is well known that the alveolar ridge is rapidly reabsorbed during the first 6 months after dental extraction and several

\footnotetext{
*Correspondence: Isaez@ucm.es

'Department of Dental Clinical Specialties, Faculty of Dentistry, Complutense University of Madrid, Plaza Ramón y Cajal S/N, 28040 Madrid, Spain Full list of author information is available at the end of the article
}

factors such as the presence of periodontal disease, periapical pathology, trauma, or the patient's systemic condition can increase resorption even before tooth loss [3]. These changes lead to alveolar bone defects making the long-term function and esthetic success of rehabilitations with dental implants a challenge [4].

Commonly, an atrophic or severely deficient edentulous ridge will require bone augmentation either simultaneous to implant placement or in a staged approach 
[5]. Surgical procedures for horizontal bone augmentation have been studied with high predictable results, low complication rates, and implant survival rates of 97$100 \%[5,6]$. However, vertical ridge augmentation is a more biologically demanding technique and has been associated with higher complications rates and less predictable results due to its high sensitivity [7]. In addition, these augmentation procedures often require a staged approach, as in alveolar osteogenesis distraction, guided bone regeneration (GBR), or reconstruction with bone blocks, which involve high morbidity and longer treatment time [7, 8].

In order to overcome these drawbacks, the bone ring technique (BRT) has been described as a one-stage approach for vertical ridge augmentation, in which an autogenous or allogeneic cortico-cancellous bone block graft is stabilized with a simultaneously inserted dental implant [9]. Several case reports and case series using BRT have been published but there is not enough evidence for its long-term efficacy [10-12].

To the best of our knowledge, no previous reviews have evaluated the clinical outcomes of BRT. Therefore, the aim of this systematic review was to assess the clinical performance of BRT, in terms of bone block and dental implant survival rates, bone gain, bone resorption, marginal bone loss, and complications.

\section{Materials and methods}

\section{Review development and PICO question}

The systematic review was designed in accordance with the PRISMA (Preferred Reporting Items for Systematic Review and Meta-Analyses) statement [13] with the following PICO (Population, Intervention, Comparison, Outcome) model:

- Population: systemically healthy edentulous and partially edentulous patients.

- Intervention: vertical ridge augmentation with BRT and simultaneous implant placement.

- Comparison: other vertical alveolar ridge augmentation procedures at dental implant sites.

- Outcome: clinical performance of BRT in terms of bone block and dental implant survival rates, bone gain, bone resorption, marginal bone loss, and complications.

\section{The PICO question was}

"In situations in which vertical ridge augmentation is required to restore partially or fully edentulous patients (population), what is the clinical performance (outcome) of bone ring technique (intervention) compared with other vertical augmentation procedures (comparison)?"

\section{Eligibility criteria}

The inclusion criteria were (1) human clinical studies including randomized controlled trials, prospective studies, retrospective studies, case series, and case reports; (2) studies in which interventions aimed to restore fully or partially edentulous patients using BRT with simultaneous implant placement; (3) any publication date; and (4) studies written in English, German, or Spanish (4).

The following outcomes were evaluated: (1) bone gain and bone resorption after BRT; (2) survival rates of bone ring blocks and implants placed after BRT; (3) marginal bone loss around implants placed with BRT; (4) associated complications.

Exclusion criteria were (1) animal studies, in vitro studies, finite element studies, review articles, technical notes and; (2) studies for which the full text was not available.

\section{Search strategy}

An electronic search was conducted for studies published up to 16th August 2020 in four databases: (1) The National Library of Medicine (MEDLINE/PubMed) via Ovid; (2) Web of Science (WOS); (3) SCOPUS; and (4) Cochrane Central Register of Controlled Trials (CENT RAL). Two independent researchers (LMSA, LSL) made the search. The search strategy (adapted to each database) was as follows: (("bone and bones" [MeSH Terms] OR ("bone" [All Fields] AND "bones" [All Fields]) OR "bone and bones" [All Fields] OR "bone" [All Fields]) AND ring [All Fields]) AND ("dental implants" [MeSH Terms] OR ("dental" [All Fields] AND "implants" [All Fields]) OR "dental implants" [All Fields] OR ("dental" [All Fields] AND "implant" [All Fields]) OR "dental implant" [All Fields]). The electronic search was complemented by a manual search in Oral \& Maxillofacial Surgery and Implant Dentistry related journals and in the reference sections of the studies reviewed. To perform the screening process all the references were included into EndNote X9 Library (Clarivate Analytics, Philadelphia, PE, USA).

\section{Data collection}

After the electronic database search, the studies and references identified were screened independently by two pre-calibrated independent reviewers (FPG and PMM). After duplicates and triplicates were removed, the titles and abstracts of the remaining articles were checked for relevance. Any disagreement in the selection process was resolved by discussion with a third reviewer (JCBB). Data from each included article was collected by the reviewers (LMSA and LSL) working together and entered on an Excel spreadsheet (Version 15.17, Microsoft Inc. 2015), including the following: authors, year of publication, study design, number of patients, number of 
implants, intervention, follow-up, outcomes evaluated, and complications.

\section{Risk of bias in individual studies}

The methodological quality of the included studies was assessed by two independent reviewers (LMSA, LSL). Any disagreement was solved by a third reviewer (JCBB).

Newcastle-Ottawa Quality Assessment Scale tool [14] was used to assess the quality of observational studies, which included a questionnaire divided into 3 categories: selection (4 questions), comparability (1 question), and exposure (3 questions). Each study could obtain a maximum of nine stars. The studies were classified in good, fair or poor-quality (GQ, FQ, or PQ) following the score algorithm proposed by the Agency for Healthcare Research and Quality [15].
The Joanna Briggs Institute Critical Appraisal tool for case reports [16] was used to assess risk of bias in case reports. This includes eight questions; a low risk of bias was considered when $\geq 50 \%$ of the answers were "yes," high risk when $\geq 50 \%$ were "no", and uncertain risk of bias if $\geq 50 \%$ of the answers were "unclear."

\section{Results}

\section{Study selection (Fig. 1)}

The initial search yielded 472 references, resulting 278 when duplicates and triplicates were discarded. After title and abstract screening, 252 articles were excluded: 241 studies because they were not related to BRT, while the other 11 were not written in English, Spanish or German. After reading the full text of the 26 selected articles, 10 were discarded for the following reasons: they were animal studies $(n=6)$; in vitro studies $(n=2)$;

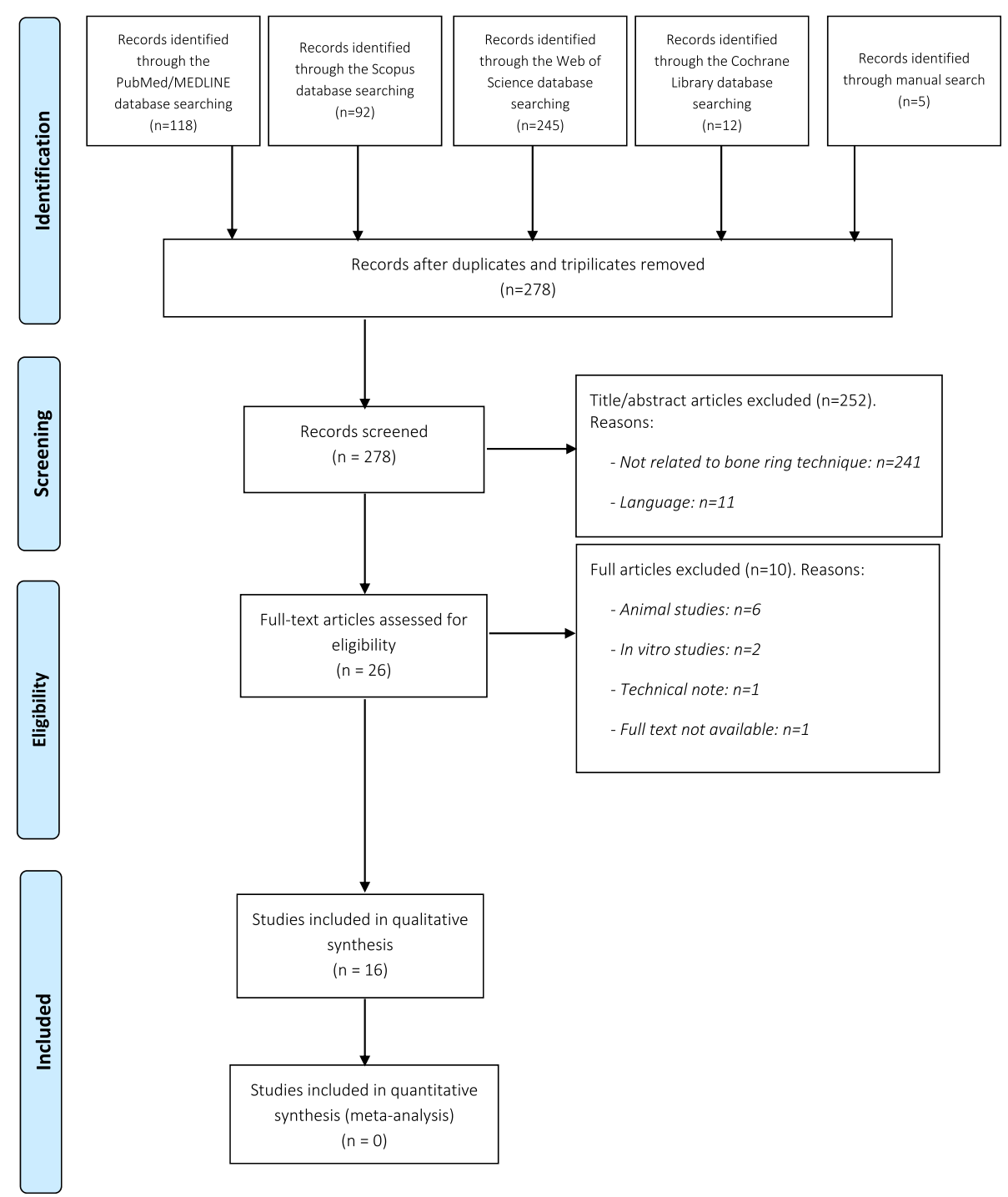

Fig. 1 PRISMA flow diagram of the screening and selection process 
technical note $(n=1)$; or the full text was unavailable ( $n$ $=1$ ). Finally, 16 articles were included in the review. The PRISMA Flow diagram in Fig. 1 illustrates the study selection process. Information about the studies reviewed is summarized in Tables 1 and 2. The studies included were non-randomized comparative clinical trials $(n=2)$; prospective studies $(n=3)$; retrospective studies $(n=2)$; case series $(n=4)$; and case reports $(n=5)$. All studies were published between 2005 and 2020 .

\section{Study characteristics (Table 1)}

All the studies together included a total of 186 patients treated with 266 implants. Out of the total of 266 implants, 219 were placed with BRT and 47 with other vertical ridge augmentation procedures. Among the 219 implants placed with BRT, 121 cases corresponded to an autogenous bone ring, of which 118 were harvested from the chin and 3 from the ramus. In the other 98 cases, an allogeneic bone ring was used. All the studies performing vertical ridge augmentation with allogeneic bone ring used resorbable collagen membranes to cover the grafted area. In one study, a platelet-rich fibrin (PRF) membrane was placed to cover the area grafted with an autogenous bone ring [21]. Regarding the intervention, BRT was used for vertical ridge augmentation in 14 studies, while in 2 studies BRT was used for sinus floor elevation. In two studies, BRT was compared with other regeneration procedures $[10,11]$. The studies had a mean follow-up period of $17.17 \pm 11.65$ months. The longest follow-up was 3.1 years [18] and the shortest was 6 months [10, $19,22,24,28]$.

\section{Results of individual studies (Table 2) Bone gain}

Bone gain evaluated through cone beam computed tomography $(\mathrm{CBCT})$ was registered in four of the studies $[10,11,21,24]$. The maximum bone height gain reported was $13.07 \mathrm{~mm}$ [24] and the minimum was 3.09 $\mathrm{mm}$ [10] with an overall mean of $4.94 \mathrm{~mm}$ across the four studies. Regarding comparative studies, Chandra et al. [10] found significant differences in terms of bone gain for BRT compared with GBR with sticky bone

Table 1 Study characteristics

\begin{tabular}{|c|c|c|c|c|c|}
\hline Author-year & Type of study & $N$ & $\begin{array}{l}N, \\
\text { IOI }\end{array}$ & Intervention & Follow-up \\
\hline Chandra et al. 2019 [10] & $\begin{array}{l}\text { Non randomized comparative clinical } \\
\text { study }\end{array}$ & 34 & 34 & $\begin{array}{l}\text { Autogenous bone ring (chin) (BR group) } \\
\text { vs sticky bone } \\
+ \text { collagen membrane (SB group) } \\
\text { IOl at } 6 \text { months }\end{array}$ & 6 months \\
\hline Flanagan et al. 2016 [17] & Case series & 8 & 8 & $\begin{array}{l}\text { Allogenic bone ring }+\mid \mathrm{OI}+\text { allograft }+ \text { collagen } \\
\text { membrane }\end{array}$ & 1 year \\
\hline Fukuda et al. 2005 [18] & Case series & 9 & 13 & Autogenous bone ring (chin) $+\mid \mathrm{IO}$ & 3.1 years \\
\hline $\begin{array}{l}\text { Giesenhagen et al. } 2018 \\
\text { [19] }\end{array}$ & Case report & 1 & 1 & Allogenic bone ring $+|\mathrm{I}|+$ collagen membrane & 6 months \\
\hline $\begin{array}{l}\text { Giesenhagen et al. } 2019 \\
\text { [20] }\end{array}$ & Case series & 3 & 7 & Allogenic bone ring $+|\mathrm{I}|+$ collagen membrane & 36 months \\
\hline Giraddi et al. 2017 [21] & Prospective study & 14 & 15 & Autogenous bone ring (chin) $+\mid \mathrm{IOI}+$ PRF membrane & 9 months \\
\hline Miller J. 2019 [22] & Case report & 1 & 1 & $\begin{array}{l}\text { Allogenic bone ring }+ \text { xenograft }+|\mathrm{O}|+\text { collagen } \\
\text { membrane }\end{array}$ & 6 months \\
\hline Nord et al. 2019 [23] & Retrospective study & 51 & 81 & $\begin{array}{l}\text { Allogenic bone ring + autogenous bone chips }+|O| \\
+ \text { collagen membrane }\end{array}$ & 12 months \\
\hline Omara et al. 2016 [24] & Prospective study & 10 & 12 & Autogenous bone ring (chin) $+\mid \mathrm{IO}$ & 6 months \\
\hline Peñarrocha et al. 2005 [25] & Case report & 1 & 3 & Autogenous bone ring (ramus) $+\mid \mathrm{|O}$ & 2 years \\
\hline Rizzo et al. 2017 [26] & Case series & 4 & 4 & $\begin{array}{l}\text { Crestal sinus floor elevation with autogenous bone ring } \\
\text { (chin) and simultaneous } \mathrm{IOI}\end{array}$ & 3 years \\
\hline Sindel et al. 2018 [27] & Retrospective study & 10 & 10 & $\begin{array}{l}\text { Sinus floor elevation with autogenous bone ring } \\
\text { (chin) and simultaneous } \mathrm{IOI}\end{array}$ & $\begin{array}{l}24.3 \\
\text { months }\end{array}$ \\
\hline Stevenes et al. 2010 [28] & Case report & 1 & 4 & Autogenous bone ring (chin) $+\mid \mathrm{IO}$ & 6 months \\
\hline Tekin et al. 2011 [29] & Case report & 1 & 1 & Autogenous bone ring $($ chin $)+\mid \mathrm{IO}$ & 1 year \\
\hline $\begin{array}{l}\text { Wychowansky et al. } 2020 \\
\text { [11] }\end{array}$ & $\begin{array}{l}\text { Non randomized comparative clinical } \\
\text { study }\end{array}$ & 30 & 60 & $\begin{array}{l}\text { Autogenous bone ring (chin) + simultaneous }|O| \\
\text { (BR group) vs xenograft tunnel (XG group) and } \\
\text { delayed IOI after } 6 \mathrm{~m}\end{array}$ & 24 months \\
\hline Yuce et al. 2019 [12] & Prospective study & 8 & 12 & Autogenous bone ring (chin) $+\mid \mathrm{IOI}$ & 18 months \\
\hline
\end{tabular}


Table 2 Results of individual studies

\begin{tabular}{|c|c|c|c|c|c|c|c|}
\hline Author, year & $\begin{array}{l}\text { Bone } \\
\text { density }\end{array}$ & Bone gain & Bone resorption & MBL & $\begin{array}{l}\text { Survival } \\
\text { rate }\end{array}$ & Other findings & Complications \\
\hline $\begin{array}{l}\text { Chandra et al. } \\
2019[10]\end{array}$ & $\begin{array}{l}\text { a) BR group: } \\
596.2 \pm 115.2 \\
H U \\
\text { b) SB group: } \\
659.6 \pm 133.8 \\
\mathrm{HU} \\
{ }^{*}(p<0.001)\end{array}$ & $\begin{array}{l}\text { a) BR group: } 3.09 \mathrm{~mm} \\
\text { (buccal) and } 3.31 \mathrm{~mm} \\
\text { (lingual) } \\
\text { b) } S B \text { group: } 1.90 \mathrm{~mm} \\
\text { (buccal) and } 1.99 \mathrm{~mm} \\
\text { (lingual) } \\
*(p<0.001)\end{array}$ & - & - & $\begin{array}{l}\text { a) BR } \\
\text { group: } \\
88,23 \% \\
\text { b) } S B \\
\text { group: } \\
100 \%\end{array}$ & $\begin{array}{l}\text { Implant Stability Quotient (ISQ) } \\
\text { a) BR group: } 61.60 \pm 8.9 \\
\text { b) SB group: } 45.02 \pm 6.33 \\
\text { *( } p<0.034) \\
\text { Histological analysis } \\
\text { a) BR group: } 50.39 \% \pm 11.96 \% \\
\text { b) SB group: } 38.91 \% \pm 12.22 \% \\
\text { * }(p<0.001)\end{array}$ & $\begin{array}{l}\text { a) BR group: } \\
-2 \text { IOI and BR failure } \\
-1 \text { dehiscence } \\
-3 \text { swelling } \\
\text { b) SB group: } \\
-1 \text { dehiscence } \\
-3 \text { swelling }\end{array}$ \\
\hline $\begin{array}{l}\text { Flanagan et al. } \\
2016[17]\end{array}$ & - & - & - & - & $100 \%$ & - & No complications \\
\hline $\begin{array}{l}\text { Fukuda et al. } \\
2005[18]\end{array}$ & - & - & - & - & $92.3 \%$ & $\begin{array}{l}\text { Radiological stability between } \\
\text { baseline and } 1.3 \text { years (periapical } \\
\mathrm{Rx} \text { ) }\end{array}$ & $1 \mathrm{IOI}$ and $\mathrm{BR}$ failure \\
\hline $\begin{array}{l}\text { Giesenhagen } \\
\text { et al. } 2018 \text { [19] }\end{array}$ & - & - & - & - & $100 \%$ & $\begin{array}{l}\text { Radiological stability between } \\
\text { baseline and } 6 \mathrm{~m} \text { (panoramic Rx) }\end{array}$ & No complications \\
\hline $\begin{array}{l}\text { Giesenhagen } \\
\text { et al. } 2019 \text { [20] }\end{array}$ & - & - & - & - & $100 \%$ & $\begin{array}{l}\text { Clinical and radiological stability } \\
\text { between baseline and } 2 \text { year } \\
\text { (panoramic Rx) }\end{array}$ & - \\
\hline $\begin{array}{l}\text { Giraddi et al. } \\
2017 \text { [21] }\end{array}$ & - & $\begin{array}{l}\text {-Mesial bone gain: } 3.70 \\
\pm 1.10 \mathrm{~mm} \\
\text {-Distal bone gain: } 3.69 \\
\pm 1.10 \mathrm{~mm}\end{array}$ & $\begin{array}{l}\text {-Mesial bone } \\
\text { resorption: } 0.73 \pm \\
0.38 \mathrm{~mm} \\
\text {-Distal bone } \\
\text { resorption: } 0.78 \pm \\
0.23 \mathrm{~mm}\end{array}$ & - & $93.33 \%$ & - & $1 \mathrm{IOI}$ and BR failure \\
\hline $\begin{array}{l}\text { Miller J. } 2019 \\
\text { [22] }\end{array}$ & - & - & - & - & $100 \%$ & $\begin{array}{l}\text { Radiological stability between } \\
\text { baseline and } 6 \text { m (periapical Rx) } \\
\text { ISQ } 68 \text { at } 6 \text { m }\end{array}$ & No complications \\
\hline $\begin{array}{l}\text { Nord et al. } \\
2019 \text { [23] }\end{array}$ & - & - & - & $\begin{array}{l}0.43 \\
\mathrm{~mm}\end{array}$ & $97.5 \%$ & - & $2 \mathrm{IOI}$ failure \\
\hline $\begin{array}{l}\text { Omara et al. } \\
2016[24]\end{array}$ & $\begin{array}{l}\text {-Mesial } \\
\text { aspect: } \\
420.43 \mathrm{HU} \\
\text {-Distal aspect: } \\
325.28 \mathrm{HU}\end{array}$ & $13.07 \pm 1.37 \mathrm{~mm}$ & $0.26 \pm 0.86 \mathrm{~mm}$ & - & $100 \%$ & - & $\begin{array}{l}2 \text { transient numbness of } \\
\text { lower lip }\end{array}$ \\
\hline $\begin{array}{l}\text { Peñarrocha } \\
\text { et al. } 2005 \text { [25] }\end{array}$ & - & - & - & - & $100 \%$ & $\begin{array}{l}\text { Radiological stability between } \\
\text { baseline and } 2 \text { years (panoramic } \\
\text { Rx) }\end{array}$ & No complications \\
\hline $\begin{array}{l}\text { Rizzo et al. } \\
2017 \text { [26] }\end{array}$ & - & - & - & z & $100 \%$ & $\begin{array}{l}\text { Radiological stability between } \\
\text { baseline and } 6 \text { years (periapical Rx) }\end{array}$ & No complications \\
\hline $\begin{array}{l}\text { Sindel et al. } \\
2018[27]\end{array}$ & - & - & - & $\begin{array}{l}1.77 \\
\mathrm{~mm}\end{array}$ & $90 \%$ & - & $1 \mathrm{IOI}$ and BR failure \\
\hline $\begin{array}{l}\text { Stevenes et al. } \\
2010[28]\end{array}$ & - & - & - & - & $100 \%$ & - & No complications \\
\hline $\begin{array}{l}\text { Tekin et al. } \\
2011[29]\end{array}$ & - & - & - & - & $100 \%$ & $\begin{array}{l}\text { Radiological stability between } \\
\text { baseline and } 6 \text { years (periapical Rx) }\end{array}$ & No complications \\
\hline $\begin{array}{l}\text { Wychowansky } \\
\text { et al. } 2020 \text { [11] }\end{array}$ & - & $\begin{array}{l}\text { a) BR group: } 4.3 \pm 1.3 \\
\text { mm } \\
\text { b) } X G \text { group: } 4.4 \pm 1.5 \\
\text { mm }\end{array}$ & - & - & $\begin{array}{l}\text { a) } B R \\
\text { group: } \\
86,66 \% \\
\text { b) } X G \\
\text { group: } \\
96,66 \%\end{array}$ & $\begin{array}{l}\text { Implant stability at baseline } \\
\text { (periotest) } \\
\text { a) } B R \text { group: }-3.2 \pm 1.3 \\
\text { b) XG group: }-1.2 \pm 1.6 \\
\text { * }(p<0,005) \\
\text { Implant stability at } 24 \mathrm{~m} \text { (periotest) } \\
\text { a) BR group: }-3.7 \pm 1.1 \\
\text { b) } X G \text { group: }-3.6 \pm 1.2 \\
\text { * }(p<0.005)\end{array}$ & $\begin{array}{l}\text { a) BR group: } \\
\text {-4 IOI failure } \\
\text { b) XG group: } \\
\text {-1 IOI failure }\end{array}$ \\
\hline $\begin{array}{l}\text { Yuce et al. } \\
2019[12]\end{array}$ & - & - & - & - & $100 \%$ & - & $\begin{array}{l}1 \text { BR failure (defect } \\
\text { repaired and IOI } \\
\text { osseointegrated) }\end{array}$ \\
\hline
\end{tabular}


technique $(p<0.001)$ (Table 1$)$, while Wychowansky et al. [11] registered a higher bone gain for vertical tunnel bone augmentation with xenograft compared with BRT.

\section{Bone resorption}

Two studies assessed bone resorption after BRT. The maximum value recorded was $0.94 \pm 0.86 \mathrm{~mm}$ [24] and the minimum $0.78 \pm 0.23 \mathrm{~mm}$ [21] with a mean bone resorption $0.83 \mathrm{~mm}$.

\section{Marginal Bone Loss (MBL)}

Mean MBL of $0.57 \mathrm{~mm}$ was obtained after a mean follow-up period of 13.35 months. The highest value was reported by Sindel et al. [27] with $1.77 \mathrm{~mm} \mathrm{MBL}$ after 24 months, while the minimum was 0.43 after a 12month follow-up reported by Nord et al. [23].

\section{Bone ring survival rate}

Six bone ring failures among the total of 219 bone rings placed were recorded, with a mean bone ring survival rate of $97.26 \%$. All the failures registered affected autogenous bone rings. Consequently, the allogeneic bone ring survival rate was $100 \%$, while the autogenous bone ring survival rate was $95.04 \%$.

\section{Implant survival rate}

The implant survival rate ranged between $86.6 \%$ and $100 \%$ across the studies with a mean survival rate of 94.97\% (208 out of 219). Regarding the intervention studied and the type of bone ring used, implants placed with autogenous bone rings for vertical ridge augmentation procedures showed a $92.51 \%$ survival rate after a mean follow-up of 17.01 months. Implants placed with autogenous bone rings for sinus floor elevation obtained a $92.85 \%$ survival rate after 27.64 months follow-up; and the highest survival rate was found with allogeneic bone rings, with $97.93 \%$ after a mean follow-up period of 12.70 months.

\section{Complications}

Among the 219 implants placed with BRT, 11 osseointegration failures were recorded (5.03\%). In addition, the studies reported three cases of swelling (1.94\%), two cases of transient numbness of the lower lip (1.29\%), and

Table 3 Quality assessment of observational studies using the Newcastle-Ottawa scale

\begin{tabular}{|c|c|c|c|c|c|c|c|c|c|c|c|}
\hline & $\begin{array}{l}\text { Wychowansky } \\
\text { et al. } 2020 \\
{[11]}\end{array}$ & $\begin{array}{l}\text { Yuce } \\
\text { et al. } \\
2019 \\
{[12]}\end{array}$ & $\begin{array}{l}\text { Nord } \\
\text { et al. } \\
2019 \\
{[23]}\end{array}$ & $\begin{array}{l}\text { Giesenhagen } \\
\text { et al. } 2019 \\
{[20]}\end{array}$ & $\begin{array}{l}\text { Chandra } \\
\text { et al. } \\
2019 \\
{[10]}\end{array}$ & $\begin{array}{l}\text { Sindel } \\
\text { et al. } \\
2018 \\
{[27]}\end{array}$ & $\begin{array}{l}\text { Giraddi } \\
\text { et al. } \\
2017 \\
{[21]}\end{array}$ & $\begin{array}{l}\text { Rizzo } \\
\text { et al. } \\
2017 \\
{[26]}\end{array}$ & $\begin{array}{l}\text { Flanagan } \\
\text { et al. } \\
2016[17]\end{array}$ & $\begin{array}{l}\text { Omara } \\
\text { et al. } \\
2016 \\
{[24]}\end{array}$ & $\begin{array}{l}\text { Fukuda } \\
\text { et al. } \\
2005 \\
{[18]}\end{array}$ \\
\hline \multicolumn{12}{|l|}{ Selection } \\
\hline $\begin{array}{l}\text { - Representativeness of } \\
\text { the exposed cohort }\end{array}$ & * & * & * & * & * & * & * & * & * & * & * \\
\hline $\begin{array}{l}\text { - Selection of the non- } \\
\text { exposed cohort }\end{array}$ & $*$ & * & * & * & * & $*$ & * & $*$ & * & * & * \\
\hline $\begin{array}{l}\text { - Ascertainment of } \\
\text { exposure }\end{array}$ & $*$ & * & * & * & * & $*$ & * & $*$ & $*$ & * & * \\
\hline $\begin{array}{l}\text { - Demonstration that } \\
\text { outcome of interest } \\
\text { was not present at } \\
\text { start of study }\end{array}$ & $*$ & $*$ & * & $*$ & $*$ & $*$ & * & $*$ & $*$ & $*$ & * \\
\hline \multicolumn{12}{|l|}{ Comparability } \\
\hline $\begin{array}{l}\text { - Study controls for } \\
\text { bone ring group }\end{array}$ & $*$ & & & & $*$ & & & & & & \\
\hline $\begin{array}{l}\text { - Study control for any } \\
\text { additional factor } \\
\text { (duration of exposure) }\end{array}$ & $*$ & & & & * & & & & & & \\
\hline \multicolumn{12}{|l|}{ Outcome } \\
\hline $\begin{array}{l}\text { - Assessment of } \\
\text { outcome }\end{array}$ & $*$ & $*$ & $*$ & $*$ & * & $*$ & * & $*$ & $*$ & $*$ & * \\
\hline $\begin{array}{l}\text { - Was follow-up long } \\
\text { enough for outcomes } \\
\text { to occur? }\end{array}$ & $*$ & $*$ & $*$ & $*$ & & $*$ & & $*$ & $*$ & & * \\
\hline $\begin{array}{l}\text { - Adequacy of follow } \\
\text { up of cohorts }\end{array}$ & $*$ & $*$ & * & $*$ & & * & & $*$ & $*$ & & * \\
\hline $\begin{array}{l}\text { Newcastle-Ottawa } \\
\text { scale }\end{array}$ & 9 & 7 & 7 & 7 & 9 & 7 & 5 & 7 & 7 & 5 & 7 \\
\hline
\end{tabular}


one wound dehiscence (0.64\%) among the patients treated with BRT.

\section{Risk of bias (Tables 3 and 4)}

Based on the Newcastle-Ottawa scale [14] two studies showed good quality, six studies were classed as presenting fair quality while two studies [21, 24] were rated as poor quality mainly due to their short follow-up periods. All the case reports included in this review showed a low risk of bias according to the Joanna Briggs Institute Critical Appraisal tool [16].

\section{Discussion}

This systematic review aimed to analyze the clinical efficacy of BRT for restoring vertical alveolar ridge defects with simultaneous dental implant placement in terms of bone gain, bone resorption, MBL, survival rates of bone rings and implants, and complications. To the best of the authors' knowledge, this is the first systematic review to evaluate the clinical outcomes of BRT.

A total of 186 patients treated with 266 dental implants were included in the review. Of the total $266 \mathrm{im}$ plants, 219 were placed with BRT. In 121 cases an autogenous bone ring was used, while the other 98 cases were performed using an allogeneic bone ring.

Unlike most of the techniques described for vertical ridge augmentation, the main clinical advantage of BRT is the possibility of a simultaneous approach, reconstructing a vertical alveolar ridge defect at the same time as implant placement, which reduces treatment time considerably. In addition, placing allogeneic bone rings can reduce or eliminate several complications related to autogenous bone block harvesting, such as the higher morbidity, the need for a donor site, neurosensorial disturbances, and the limited amount of bone available, among others [30, 31].

The most common complications observed after BRT were swelling $(1.94 \%)$, transient numbness of the lower lip $(1.29 \%)$, and wound dehiscence $(0.64 \%)$. In any case, according to these findings, BRT showed a low rate of complications regardless of the type of bone ring used.

Nevertheless, BRT presents certain drawbacks: firstly, a minimum of 3-4 $\mathrm{mm}$ of apical native bone are required to stabilize the implant and the bone ring [32]; and secondly, most of the cases published describe single implants, and so there is a lack of evidence for the efficacy of BRT in large defects and multiple implant placement.

Regarding bone gain and subsequent resorption, a mean gain of $4.94 \mathrm{~mm}$ and mean bone resorption of $0.83 \mathrm{~mm}$ were observed. Consequently, a vertical bone gain of around $4 \mathrm{~mm}$ can be expected with BRT. Similar results have been described in a recent systematic review which evaluated the effectiveness of vertical ridge augmentation using various different techniques, which obtained a mean vertical bone gain of $4.16 \mathrm{~mm}$ [7].

According to Urban et al. [7], mean MBL of 1.01 can be expected around implants placed in augmented sites during the first year. The studies included in the present review showed a mean MBL of $0.57 \mathrm{~mm}$ after a mean follow-up of 13.35 months. So, based on the present findings, BRT would appear to undergo less resorption than other vertical GBR procedures.

The mean survival rate obtained in the present review was $97.26 \%$; with $100 \%$ for allogeneic bone rings and 95.04\% for autogenous bone rings. These outcomes are similar to other vertical ridge augmentation procedures $[7,30,33]$.

Table 4 Quality assessment of case reports using the Joanna Briggs Institute Critical Appraisal tools

\begin{tabular}{|c|c|c|c|c|c|}
\hline Study & $\begin{array}{l}\text { Miller J. } \\
2019[22]\end{array}$ & $\begin{array}{l}\text { Giesenhagen } \\
\text { et al. } 2018[19]\end{array}$ & $\begin{array}{l}\text { Tekin et al. } \\
2011[29]\end{array}$ & $\begin{array}{l}\text { Stevenes et al. } \\
2010[28]\end{array}$ & $\begin{array}{l}\text { Peñarrocha et al. } \\
2005[25]\end{array}$ \\
\hline $\begin{array}{l}\text { Were patient's demographic characteristics clearly } \\
\text { described? }\end{array}$ & + & + & + & + & + \\
\hline $\begin{array}{l}\text { Was the patient's history clearly described and } \\
\text { presented as a timeline? }\end{array}$ & + & - & - & - & + \\
\hline $\begin{array}{l}\text { Was the current clinical condition of the patient on } \\
\text { presentation clearly described? }\end{array}$ & + & + & + & + & + \\
\hline $\begin{array}{l}\text { Were diagnostic tests or assessment methods and } \\
\text { the results clearly described? }\end{array}$ & - & + & $?$ & + & + \\
\hline $\begin{array}{l}\text { Was the intervention or treatment procedure clearly } \\
\text { described? }\end{array}$ & + & + & + & + & + \\
\hline $\begin{array}{l}\text { Was the post-intervention clinical condition clearly } \\
\text { described? }\end{array}$ & + & + & + & + & + \\
\hline $\begin{array}{l}\text { Were adverse events (harms) or unanticipated events } \\
\text { identified and described? }\end{array}$ & + & + & + & + & + \\
\hline Does the case report provide takeaway lessons? & - & + & + & + & + \\
\hline
\end{tabular}

$+=$ yes, $-=$ no, $?=$ unclear 
Of the 219 dental implants placed with BRT analyzed in the review, the survival rate of implants placed with BRT was $94.97 \%$ after a mean follow-up of $17.17 \pm 11.65$ months. It should be noted that the highest values were found with allogeneic bone rings, with a $97.93 \%$ survival rate after a 12.70-month follow-up. These findings agree with previous systematic reviews analyzing implant survival rates after GBR and bone block grafting, which report survival rates of between $97 \%$ and 100\% [5-7, 30].

Regarding the surgical technique, the included studies presented a lack of homogeneity. Therefore, further investigation of many aspects of BRT are needed in order to establish a clear and validated protocol regarding the use of membranes or whether or not to perform the technique as a single stage or in a staged approach. In this sense, animal studies have demonstrated that the use of membranes in BRT does not appear to offer any clinical advantage [34, 35], and no clinical differences have been observed between simultaneous implant placement or a staged procedure [36, 37].

In spite of the promising results for survival rate, bone gain, MBL, and the rate of complications, no long-term RCTs have compared BRT with other vertical ridge augmentation procedures. Moreover, the studies included in this review presented a lack of homogeneity in the surgical protocols followed. Therefore, there is insufficient evidence to reach any firm conclusions about long-term predictability of BRT.

\section{Conclusions}

According to the findings of this systematic review, it may be concluded that BRT could be a valid option for restoring single vertical defects with dental implants in terms of bone gain, implant survival rates, and complications. BRT with simultaneous to dental implant insertion aims to shorten treatment time and reduce morbidity, especially when an allogeneic bone ring is used. However, further studies comparing BRT with other vertical ridge augmentation procedures with longer follow-up periods are needed in order to value the efficacy of BRT in different clinical scenarios.

\section{Abbreviations}

GBR: Guided bone regeneration; BRT: Bone ring technique; PRF: Platelet-rich fibrin; CBCT: Cone beam computed tomography; MBL: Marginal bone loss

\section{Acknowledgements}

Not applicable.

Authors' contributions

All authors read and approved the final manuscript.

Funding

The authors received no funding for this work.

Availability of data and materials

All the data generated in the course of this systematic review were included in the manuscript.
Ethics approval and consent to participate

Not applicable.

\section{Consent for publication}

Not applicable.

\section{Competing interests}

Luis Miguel Sáez-Alcaide, Jorge Cortés-Bretón Brinkmann, Luis SánchezLabrador, Fabián Pérez-González, Pedro Molinero-Mourelle and Juan LópezQuiles declare that they have no competing interests.

\section{Author details}

${ }^{1}$ Department of Dental Clinical Specialties, Faculty of Dentistry, Complutense University of Madrid, Plaza Ramón y Cajal S/N, 28040 Madrid, Spain.

${ }^{2}$ Department of Conservative Dentistry and Orofacial Prosthodontics, Faculty of Dentistry, Complutense University of Madrid, Madrid, Spain. ${ }^{3}$ Department of Reconstructive Dentistry and Gerodontology, School of Dental Medicine, University of Bern, Bern, Switzerland.

Received: 18 August 2020 Accepted: 20 November 2020

Published online: 12 December 2020

\section{References}

1. Araújo MG, da Silva JCC, de Mendonça AF, Lindhe J. Ridge alterations following grafting of fresh extraction sockets in man. A randomized clinical trial. Clin Oral Implants Res. 2015;26:407-12.

2. Araújo MG, Lindhe J. Dimensional ridge alterations following tooth extraction. An experimental study in the dog. J Clin Periodontol. 2005;32: 212-8.

3. Lang NP, Zitzmann NU, Working Group 3 of the VIII European Workshop on Periodontology. Clinical research in implant dentistry: evaluation of implantsupported restorations, aesthetic and patient-reported outcomes. J Clin Periodontol. 2012;39:133-8.

4. Clementini M, Tiravia L, De Risi V, Vittorini Orgeas G, Mannocci A, de Sanctis M. Dimensional changes after immediate implant placement with or without simultaneous regenerative procedures: A systematic review and meta-analysis. J Clin Periodontol. 2015;42:666-77.

5. Sanz-Sánchez I, Ortiz-Vigón A, Sanz-Martín I, Figuero E, Sanz M. Effectiveness of lateral bone augmentation on the alveolar crest dimension: a systematic review and meta-analysis. J Dent Res. 2015;94:128-42.

6. Elnayef B, Porta C, Suárez-López Del Amo F, Mordini L, Gargallo-Albiol J, Hernández-Alfaro F. The fate of lateral ridge augmentation: a systematic review and meta-analysis. Int J Oral Maxillofac Implants. 2018;33:622-35.

7. Urban IA, Montero E, Monje A, Sanz-Sánchez I. Effectiveness of vertical ridge augmentation interventions: A systematic review and meta-analysis. J Clin Periodontol. 2019;46:319-39.

8. Clementini M, Morlupi A, Agrestini C, Barlattani A. Immediate versus delayed positioning of dental implants in guided bone regeneration or onlay graft regenerated areas: a systematic review. Int J Oral Maxillofac Surg. 2013;42: 643-50

9. Benlidayi ME, Tatli U, Salimov F, Tukel HC, Yuksel O. Comparison of autogenous and allograft bone rings in surgically created vertical bone defects around implants in a sheep model. Clin Oral Implants Res. 2018;29: 1155-62.

10. Chandra RV, Shivateja K, Reddy AA. Autogenous bone ring transplant vs autologous growth factor-enriched bone graft matrix in extraction sockets with deficient buccal bone: a comparative clinical study. Int J Oral Maxillofac Implants. 2019:34:1424-33.

11. Wychowansky P, Wolinski J, Morawiec T, Kownacki P, Starzynska A, Kosieradzki M, Fiedor P. Preliminary clinical data and the comparison of the safety and efficacy of autogenous bone grafts versus xenograft implantations in vertical bone deficiencies before dental implant installation. Trans Proceed. 2020. Article in press; https://doi.org/10.1016/j.transproceed. 2020.02.099

12. Yuce MO, Adali E, Turk G, Isik G, Gunbay T. Three-dimensional bone grafting in dental implantology using autogenous bone ring transplant: clinical outcomes of a one-stage technique. Niger J Clin Pract. 2019;22:977-81.

13. Moher D, Liberati A, Tetzlaff J, Altman DG. Preferred reporting items for systematic reviews and meta-analyses: The PRISMA statement. Int J Surg. 2010;8:336-41. 
14. Wells GA, Shea B, O'Connel D, Peterson J, Welch V, Losos M, Tugwell P. The Newcastle-Ottawa scale (NOS) for assessing the quality of nonrandomized studies in meta-analyses. http://www.ohri.ca/pro-grams/clinical_ epidemiology/oxford.asp

15. McPheeters ML, Kripalani S, Peterson NB, Idowu RT, Jerome RN, Potter SA, Andrews JC. Closing the quality gap: revisiting the state of the science (vol. 3: quality improvement interventions to address health disparities). Evid Rep Technol Assess. 2012;208:1-475.

16. Moola S, Munn Z, Sears K, Sfetcu R, Currie M, Lisy K, Tufanaru C, Qureshi R, Mattis P, Mu P. Conducting systematic reviews of association (etiology): The Joanna Briggs Institute's approach. Int J Evid Based Healthc. 2015;13(3):1639.

17. Flanagan D. Cylindrical ringbone al- lograft to restore atrophic implant sites: a pilot study. J Oral Implantol. 2016;42:159-63.

18. Fukuda $M$, Takahashi $T$, Yamaguchi $T$. Bone grafting technique to increase interdental alveolar bone height for placement of an implant. Br J Oral Maxillofac Surg. 2000;38:16-8.

19. Giesenhagen B, Martin N, Donkiewicz P, Kačarević Ž, Smeets R, Jung O, Schnettler R, Barbeck M. Vertical bone augmentation in a single-tooth gap with an allogenic bone ring: clinical considerations. J Esthet Restor Dent. 2018:30:480-3

20. Giesenhagen B, Martin n JO, Barbeck M. Bone Augmentation and simultaneous implant placement with allogenic bone rings and analysis of its purification success. Materials. 2019;12:1291.

21. Giraddi GB, Saifi AM. Bone ring augmentation around immediate implants: a clinical and radiographic study. Ann Maxillofac Surg. 2017;7:92-7.

22. Miller RJ. A one-stage procedure to achieve predictable implant placement and guided bone regeneration. Compend Contin Educ Dent. 2019:40:1-3.

23. Nord T, Yüksel O, Grimm WD, Giesenhagen B. One-stage vertical ridge augmentation and dental implantation with allograft bonerings: results 1 year after surgery. J Oral Implantol. 2019;45:457-63.

24. Omara M, Abdelwahed N, Ahmed M, Hindy M. Simultaneous implant placement with ridge augmentation using an autogenous bone ring transplant. Int J Oral Maxillofac Surg. 2016;45:535-44.

25. Penarrocha-Diago M, Gomez-Adrian MD, Garcia-Mira B, Ivorra-Sais M. Bone grafting simultaneous to implant placement. Presentation of a case. Med Oral Patol Oral Cir Bucal. 2005;10:444-7.

26. Rizzo R, Checchi V, Marsili F, Zani A, Incerti-Parenti S, Checchi L. A new transalveolar sinus lift procedure for single implant placement: the ebanist technique. A technical description and case series. Open Dent J. 2017;31: 187-99.

27. Sindel A, Ozarslan MM, Ozalp O. Intrasinusal locking technique: a novel use of the ring block technique at sinus perforations for simultaneous implant placement. Int J Oral Maxillofac Surg. 2018;47:499-504.

28. Stevens MR, Emam HA, Alaily ME, Sharawy M. Implant bone rings. Onestage three-dimensional bone transplant technique: A case report. J Oral Implantol. 2010;36:69-74.

29. Tekin U, Kocyigit DI, Sahin V. Symphyseal bone cylinders tapping with the dental implant into insufficiency bone situated esthetic area at one-stage surgery: a case report and the description of the new technique. J Oral Implantol. 2011;37:589-94.

30. Pérez-González F, Molinero-Mourelle P, Sánchez-Labrador L, Sáez-Alcaide LM, Limones A, Cortes-Breton Brinkmann J, López-Quiles J. Assessment of clinical outcomes and histomorphometric findings in alveolar ridge augmentation procedures with allogeneic bone block grafts: A systematic review and meta-analysis. Med Oral Patol Oral Cir Bucal. 2020;25:291-8.

31. Weibull L, Widmark G, Ivanoff CJ, Borg E, Rasmusson L. Morbidity after chin bone harvesting: A retrospective long-term follow-up study. Clin Impl Dent Relat Res. 2009;11:149-5.

32. Miller RJ, Korn RJ, Miller RJ. Indications for simultaneous implantation and bone augmentation using the allograft bone ring technique. Int J Perio Res Dent. 2020;40:345-52.

33. Aloy-Prósper A, Peñarrocha-Oltra D, Peñarrocha-Diago M, Peñarrocha-Diago M. The outcome of intraoral onlay block bone grafts on alveolar ridge augmentations: a systematic review. Med Oral Patol Oral Cir Bucal. 2015;1: 251-8.

34. Haga-Tsujimura M, Nakahara K, Kobayashi E, Igarashi K, Schaller B, Saulacic N. Single-staged implant placement using bone ring technique with and without membrane placement: an experimental study in the Beagle dog. Clin Oral Implants Res. 2018;29:263-76.
35. Nakahara K, Haga-Tsujimura M, Igarashi K, Kobayashi E, Schaller B, Lang NP, Saulacic N. Single-staged implant placement using the bone ring technique with and without membrane placement: Micro-CT analysis in a preclinical in vivo study. Clin Oral Implants Res. 2020;31:29-36.

36. Nakahara K, Haga-Tsujimura M, Sawada K, Kobayashi E, Schaller B, Saulacic $\mathrm{N}$. Single-staged vs. two-staged implant placement in vertically deficient alveolar ridges using bone ring technique-Part 2: Implant osseointegration. Clin Oral Implants Res. 2017;28:31-8.

37. Nakahara K, Haga-Tsujimura M, Sawada K, Kobayashi E, Mottini M, Schaller B, Saulacic N. Single-staged vs. two-staged implant placement using bone ring technique in vertically deficient alveolar ridges-Part 1: Histomorphometric and micro-CT analysis. Clin Oral Implants Res. 2016;27:1384-91.

\section{Publisher's Note}

Springer Nature remains neutral with regard to jurisdictional claims in published maps and institutional affiliations.

\section{Submit your manuscript to a SpringerOpen ${ }^{\circ}$ journal and benefit from:}

- Convenient online submission

- Rigorous peer review

- Open access: articles freely available online

High visibility within the field

- Retaining the copyright to your article

Submit your next manuscript at $\boldsymbol{\nabla}$ springeropen.com 